\title{
Future projections of biodiversity and ecosystem services in Europe with two integrated assessment models
}

\author{
Clara J. Veerkamp ${ }^{1}$ (D) Robert W. Dunford ${ }^{2,3} \cdot$ Paula A. Harrison ${ }^{4} \cdot$ Maryia Mandryk $^{1} \cdot$ Jörg A. Priess ${ }^{5}$. \\ Aafke M. Schipper ${ }^{1,6} \cdot$ Elke Stehfest $^{1} \cdot$ Rob Alkemade $^{1,7}$
}

Received: 16 July 2019 / Accepted: 10 July 2020 / Published online: 19 August 2020

(C) The Author(s) 2020

\begin{abstract}
Projections of future changes in biodiversity and ecosystem services (BES) are of increasing importance to inform policy and decision-making on options for conservation and sustainable use of BES. Scenario-based modelling is a powerful tool to assess these future changes. This study assesses the consequences for BES in Europe under four socio-environmental scenarios designed from a BES perspective. We evaluated these scenarios using two integrated assessment models (IMAGE-GLOBIO and CLIMSAVE IAP, respectively). Our results showed that (i) climate and land use change will continue to pose significant threats to biodiversity and some ecosystem services, even in the most optimistic scenario; (ii) none of the four scenarios achieved overall preservation of BES in Europe; and (iii) targeted policies (e.g. on climate change, biodiversity conservation and sustainable land management) and behavioural change (e.g. reducing meat consumption, water-saving behaviour) reduced the magnitude of BES loss. These findings stress the necessity of more ambitious policies and actions if BES in Europe are to be safeguarded. We further found that the multi-modelling approach was critical to account for complementary BES dimensions and highlighted different sources of uncertainties (e.g. related to land use allocation, driving forces behind BES changes, trade assumptions), which facilitated nuanced and contextualised insights with respect to possible BES futures.
\end{abstract}

Clara J. Veerkamp and Robert W. Dunford contributed equally to this work.

Communicated by Wolfgang Cramer

Electronic supplementary material The online version of this article (https://doi.org/10.1007/s10113-020-01685-8) contains supplementary material, which is available to authorized users.

Clara J. Veerkamp

clara.veerkamp@pbl.nl

Robert W. Dunford

rdunford@ceh.ac.uk

Paula A. Harrison

paulaharrison@ceh.ac.uk

Maryia Mandryk

maryia.mandryk@gmail.com

Jörg A. Priess

joerg.priess@ufz.de

Aafke M. Schipper

aafke.schipper@pbl.nl

Elke Stehfest

elke.stehfest@pbl.nl
Rob Alkemade

rob.alkemade@pbl.nl

1 PBL - Netherlands Environmental Assessment Agency, Postbus 30314, 2500 GH The Hague, The Netherlands

2 UK Centre for Ecology \& Hydrology, Wallingford, UK

3 Environmental Change Institute, Oxford University, Oxford, UK

4 UK Centre for Ecology \& Hydrology, Lancaster, UK

5 UFZ - Helmholtz Centre for Environmental Research, Leipzig, Germany

6 Institute for Water and Wetland Research, Radboud University, Nijmegen, The Netherlands

Environmental Systems Analyses Group, Wageningen University, Wageningen, The Netherlands 
Keywords Integrated assessment modelling · IMAGE-GLOBIO · CLIMSAVE IAP · Scenario analysis · Trade-offs · Intermodel comparison

\section{Introduction}

Biodiversity and ecosystem services (BES) are declining, with potentially serious consequences for human well-being (IPBES 2019; IPCC 2019; MA 2005a; Tittensor et al. 2014). It has been suggested that biodiversity and some ecosystem services (ES) (e.g. climate regulation, nutrient cycling) are at increasing risk of declining beyond the boundaries of humanity's 'safe operating space' (Rockström et al. 2009; Steffen et al. 2015). This has led to a proliferation of policies and international commitments striving to halt further degradation, help biodiversity recover and ensure the future provision of ES critical for human wellbeing (e.g. Aichi Biodiversity targets (CBD 2010); EU Biodiversity Strategy (EC 2011; EC 2020); UN Sustainability Developments Goals (SDGs; (UN 2015)). To deliver on these aspirations, it is imperative that decision-making is underpinned by a firm understanding of the implications of future environmental changes for BES.

In this context, scenario-based modelling can play an important role by providing insights into drivers of change and exploring plausible pathways to desirable future environments (e.g. Harmáčková and Vačkáŕ 2015; Kok et al. 2018; Mouchet et al. 2017; Posthumus et al. 2010; Priess et al. 2015; Schröter et al. 2005; Schulp et al. 2016). Scenarios describe potential futures whilst models translate these futures into projected societal and environmental consequences based on quantitative relationships between drivers (e.g. climate change, economic development) and other components of the socio-environmental system (e.g. nature) (Ferrier et al. 2016). Yet, Hauck et al. (2015) highlighted that many of the scenarios modelled to date either ignore BES (e.g. Intergovernmental Panel on Climate Change (IPCC) scenarios (IPCC 2000; O'Neill et al. 2015)) or do not systematically include BES-relevant drivers or policy options in the scenario design (e.g. Millennium Ecosystem Assessment (MA) scenarios (MA 2005b)). Thus, there is a need for more integrated environmental scenarios that place BES at the centre of the scenario development to support decisions on BES policy and management at multiple scales (Rosa et al. 2017).

In the OpenNESS project (http://www.openness-project. $\mathrm{eu} /$ ), European scenarios were developed to explicitly assess the conditions leading to changes in BES and providing a framework to assess the consequences of BES-oriented policy measures in the context of plausible socio-environmental futures (Hauck et al. 2019; Priess et al. 2018). In the present study, we aim to assess the consequences for BES in Europe under four new future socio-environmental scenarios as developed in the OpenNESS project. To that end, we used two complementary integrated assessment models (IAMs): the global IMAGE-GLOBIO model (Alkemade et al. 2009; Schipper et al. 2020; Stehfest et al. 2014) and the European CLIMSAVE Integrated Assessment Platform (IAP) (Dunford et al. 2015; Harrison et al. 2016; Harrison et al. 2015). This enabled us to quantify a broader set of BES indicators and to assess the consistency of the results, which in turn helps to identify factors underlying model uncertainty.

IAMs are particularly suited for analysing socioenvironmental futures, as they couple natural and societal systems within a single modelling framework, thus allowing more integrated projections of both societal and environmental change (Harfoot et al. 2014; Stehfest et al. 2014). More specifically, IAMs offer the possibility to quantify the impacts of multiple drivers of environmental change simultaneously, including climate change and land use and land cover (LULC) change, on various economic sectors, such as agriculture and forestry, and environmental compartments, such as water, soil and biosphere (Harfoot et al. 2014; Harrison et al. 2016; IPCC 2014). The simultaneous consideration of multiple dimensions is an essential characteristic of IAMs and it has been shown that this approach is critical to adequately assess the magnitude, spatial pattern and direction of environmental changes (Harrison et al. 2016). In turn, the more holistic assessment of socio-environmental dynamics, including BES, is vital for better-informed planning and decision-making (Harrison et al. 2016; Harrison et al. 2018; IPBES 2016; Kirchner et al. 2015).

IAMs have a long history of global-scale applications to assess likely impacts of possible changes in socioeconomic drivers on climate change to support climate policy formulation at an intergovernmental level (Harfoot et al. 2014; IPCC 2014). IAMs have also been applied to derive policy-relevant insights on BES changes at both global (Alcamo et al. 2005; Kok et al. 2018; Krause et al. 2017; Kraxner et al. 2013) and regional scales (Dunford et al. 2015; Kirchner et al. 2015; Reidsma et al. 2006; Verboom et al. 2007). However, IAMs differ considerably in terms of underlying assumptions and the representation of processes and interactions between sectors (Alexander et al. 2017; Harfoot et al. 2014; Prestele et al. 2016; Schmitz et al. 2014; Stehfest et al. 2019). For instance, Alexander et al. (2017) compared LULC projections across 18 different IAMs and demonstrated that model uncertainty was greater than scenario uncertainty. Scenario outcomes therefore depend not only on the scenario itself, but also on the IAM used to quantify the storyline, highlighting the need to account for model uncertainty in the BES projections made. 


\section{Method}

\section{Scenario development}

In the OpenNESS project, the BES-focussed scenarios for Europe were developed through an integrative and participatory development process involving a variety of stakeholders and end-users from both European and regional level, including representatives from the general public, NGOs, economic sectors, authorities and policymakers (for more detail, see Priess et al. (2018)). The scenario development entailed the creation of storylines describing plausible future socioenvironmental development pathways for Europe, varying social, technological, economic, environmental and policy developments. The four scenarios were developed at the intersection of two main axes representing key uncertainties expected to influence BES: (i) whether future policies are sectoral or integrated across sectors (cross-sectoral) and (ii) whether responsibilities are devolved between European nations or concentrated at the level of the European Union. These two axes resulted in four future worlds (Box 1): (1) United-We-Stand (UWS), (2) Wealth-Being (WB), (3) EcoCentre (EC) and (4) Rural Revival (RR) (Priess et al. 2018).

Box 1 Overview of the four scenarios (Priess et al. 2018)

United-We-Stand (UWS) - sectoral responses and concentrated responsibilities. The UWS scenario is described by the strong globalisation of trade flows and represents a world where technology is seen as a solution to environmental challenges, coordinated by a strong EU. The sectoral focus on technological solutions to individual problems, however, limits the perceived need for behavioural change and prevents an explicit focus on cross-sectoral issues such as the environment.

Wealth-Being $(W B)$ - sectoral responses and devolved responsibility. The WB scenario exemplifies a future where individualism and consumerism lead to a highly fossil fuel-dependent world driven by economic growth, yet with large disparities between countries and a lack of international cooperation and trade. Environmental policies are limited as only provision services are prioritised.

Eco-Centre (EC)—cross-sectoral responses and concentrated responsibilities. The EC scenario focuses on cross-sectoral thinking where BES is highly integrated within policy. Both technological and behavioural changes are adopted to restrict environmental impacts, leading to limited economic growth. Sustainable farming and eco-friendly behaviour are promoted. International trade is restricted to prevent outsourcing of impacts of European land use decisions.

Rural Revival (RR) — cross-sectoral responses and devolved responsibilities. The RR scenario reflects a world where localism is the focus of environmental management, including a back-to-nature movement and revitalisation of traditional farming. Policies explicitly consider cross-sectoral impacts on the environment, but decisions are made at national and sub-national scales, with limited coordination and cooperation for addressing environmental concerns.

In addition to the storylines, participants within the scenario process quantified changes in key drivers of BES, such as human population size, gross domestic product (GDP), dietary preferences and technology development. To do this, assumptions were made on specific elements highly relevant to BES-related decision-making, including some major political, social and economic changes taking place, and the attitudes to land use and environmental conservation. For example, the EC scenario includes coordinated cross-sectoral policies targeted at BES that are represented by changes in human behaviour (e.g. promoting water-saving practices, changing to lower-meat diets), environmental policies (e.g. increasing protected areas, setting aside land for nature) and technology (e.g. increasing water-saving technology, but lower increases in technological intensification). In comparison, the UWS scenario focuses on technological approaches (e.g. increasing crop productivity and water-saving technologies), with limited efforts towards behavioural change and nature conservation. The main characteristics of the scenarios are described in Table 1.

\section{Scenario implementation}

The scenario implementation involved an iterative process between the scenario development and modelling team to agree on quantitative levels for key drivers that act as input variables to the models. The modelling team included experts from a variety of relevant physical, biological and social science disciplines who specialised in climate change, land use change, biodiversity and ecosystem services. We used two IAMs: (1) 'IMAGEGLOBIO', combines the integrated assessment model IMAGE (Stehfest et al. 2014) with the GLOBIO-3.5 biodiversity model (Alkemade et al. 2009; Schipper et al. 2016), and (2) 'CLIMSAVE IAP', the CLIMSAVE Integrated Assessment Platform, a regional IAM for Europe (Dunford et al. 2015; Harrison et al. 2016; Harrison et al. 2015). Both models are capable of simulating the combined impacts of socio-economic and environmental changes (i.e. LULC and climate change) on multiple components of human-environment systems including BES (Alkemade et al. 2009; Dunford et al. 2015; Schulp et al. 2012). The models project changes in BES for a given scenario by taking into consideration a number of factors including (a) the biophysical constraints that limit or enable growth of vegetation (e.g. land characteristics, climate); (b) socio-economic factors that influence the demand for commodities (e.g. human population change, GDP and diets); and (c) socio-economic factors that modify the supply of commodities (e.g. agricultural technology, land management practices). Input variables (e.g. human population size, GDP per capita, changes in meat consumption, agricultural productivity and protected areas) and input settings were customised as closely as possible to the characteristics identified by the scenario developers (Priess et al. 2018) (Table 1 and Table S1). It was possible to fully customise the CLIMSAVE IAP to the European storylines as the model includes a userfriendly interface that allows stakeholders to manipulate its input settings (Harrison et al. 2015). Because IMAGE-GLOBIO is a global model, the key input values for the European OpenNESS scenarios (such as GDP, human population size and climate) 
Table 1 Main characteristics of the four scenarios. Symbols indicate the change relative to the baseline year (2010) and the number of symbols reflects the magnitude of change, ranging from a strong decrease (-) to strong increase (++). Blank cells reflect no change relative to the baseline

\begin{tabular}{|c|c|c|c|c|}
\hline Scenario drivers & $\begin{array}{l}\text { United-We-Stand } \\
\text { (UWS) }\end{array}$ & Wealth-Being (WB) & Eco-Centre (EC) & Rural Revival (RR) \\
\hline Policy responsibilities & Concentrated & Devolved & Concentrated & Devolved \\
\hline Policy types & Sectoral & Sectoral & Cross-sectoral & Cross-sectoral \\
\hline Population & & + & - & -- \\
\hline GDP & + & ++ & & -- \\
\hline EU imports & ++ & - & - & -- \\
\hline Technology: agricultural & ++ & ++ & + & -- \\
\hline Technology: water saving & ++ & + & ++ & \\
\hline Water-saving behaviour & - & -- & ++ & ++ \\
\hline Vegetarianism & - & -- & ++ & ++ \\
\hline $\begin{array}{l}\text { Agricultural land set aside for nature } \\
\text { conservation }\end{array}$ & & & + & + \\
\hline Protected areas & & -- & ++ & + \\
\hline Global climate context & $\mathrm{RCP} 4.5$ & $\mathrm{RCP} 8.5$ & RCP 6.0 & RCP 8.5 \\
\hline Global socio-economic context & SSP1 'Sustainability' & $\begin{array}{l}\text { SSP5 'Fossil-fuelled } \\
\text { development' }\end{array}$ & $\begin{array}{l}\text { SSP2 'Middle of the } \\
\text { road' }\end{array}$ & $\begin{array}{l}\text { SSP3 'Regional } \\
\text { Rivalry' }\end{array}$ \\
\hline
\end{tabular}

were aligned to the global storylines of the Shared Socioeconomic Pathways (SSPs) (O’Neill et al. 2015). This was achieved by matching trajectories of populations and GDP whilst taking into consideration the storyline, logic and characteristics corresponding to similar archetypes of scenarios (Cheung et al. 2016). This led to a mapping of UWS to SSP1, WB to SSP5, EC to SSP2 and RR to SSP3, and enabled IMAGE-GLOBIO to simulate plausible European developments within a consistent global context. Further, the climate change projection corresponding to the SSPs was used (Van Vuuren and Carter 2014) (Table 1 and Table S1). The CLIMSAVE IAP model has a different set of climate change scenarios integrated into its model architecture. To match the climate change input data across the two IAMs as closely as possible, the CLIMSAVE IAP simulations were based on the RCP4.5 emissions scenario coupled with the climate model which displayed the most similar spatial patterns of average precipitation and temperature to those of IMAGE-GLOBIO's SSPs in 2050. Although the exact magnitude of some scenario input values differed between the models, the relative magnitude and direction of change across the four scenarios were consistent to ensure the model outputs for BES were comparable (Table S1).

\section{Modelling and analysis}

Implications of the scenarios were calculated for a number of LULC and BES indicators (Table 2). To enhance comparability between the outputs of the two models, we used three overarching LULC classes, i.e. 'cropland', 'grassland' and 'forest' (following Alexander et al. 2017). The 'grassland' class used here includes both grass used for livestock production and areas of natural or unmanaged land that is not used for trees or crops. This corresponds to the intensive and natural grassland classes in IMAGE-GLOBIO and the intensive and extensive grassland classes represented in the CLIMSAVE IAP. In addition, the CLIMSAVE IAP's land use class 'unmanaged land' (which represents land not needed or unsuitable for agricultural production and with a low net primary productivity) was post-classified with reference to CORINE land cover (CLC 2000), to the best matching underlying land use class depending on whether it was 'forest', 'grassland' or 'non-vegetated land' in CORINE.

Nine ES indicators and two biodiversity indicators were selected from the outputs available from the two IAMs (Table 2). The selected indicators cover a broad range of BES aspects, including (i) provisioning services (i.e. wild food availability, food crop provision, timber provision, water availability), (ii) regulating services (i.e. pest control, soil erosion control, global carbon regulation) and biodiversity (i.e. mean species abundance indicator (MSA), species habitat suitability indices (SHSI)). Some of these aspects were represented by only one of the two models (hence complementary) and some were covered by both IAMs, thus allowing an assessment of model uncertainty. IMAGE-GLOBIO calculates the indicators at a $0.5^{\circ}$ by $0.5^{\circ}$ spatial resolution, whilst the CLIMSAVE IAP computes them on a finer $10^{\prime}$ by $10^{\prime}$ grid cell resolution. To provide spatially consistent datasets, the model outputs were aggregated for the European Union (i.e. EU 27), Switzerland and Norway and data were summarised to this extent. All indicators were calculated for each of the four scenarios at the end of the simulation period (2050) and for the baseline year (2010) to allow relative changes in the indicator values to be calculated as $\left(X_{2050}-X_{2010}\right) / X_{2010}$ where $X$ represents the indicator. 
Table 2 Description of output indicator variables derived from the Integrated Assessment Models (adapted from Alkemade et al. 2009; Dunford et al. 2015; Stehfest et al. 2014)

\begin{tabular}{|c|c|c|}
\hline Model & Indicator (unit) & Description \\
\hline \multicolumn{3}{|c|}{ Land use / Land cover (LULC) } \\
\hline Both & Cropland, forest, grassland & $\begin{array}{l}\text { Land use is represented by the modelled area of each land use class. Area is calculated as \% of grid } \\
\text { cell and multiplied with the area of the grid cell. }\end{array}$ \\
\hline \multicolumn{3}{|c|}{ Provisioning services } \\
\hline $\mathrm{I}-\mathrm{G}$ & Wild food availability (M ton/year) & $\begin{array}{l}\text { Wild food availability is defined by the total production of terrestrial wild food (i.e. game, } \\
\text { mushrooms and berries) potentially available based on a correlation between national and } \\
\text { international hunting and gathering statistics and land cover type (Schulp et al. 2012). }\end{array}$ \\
\hline Both & $\begin{array}{l}\text { Food crop production (ton fresh } \\
\text { weight/year) }\end{array}$ & $\begin{array}{l}\text { Food crop production is defined by the potential productivity of key food crops (i.e. cereals, rice, } \\
\text { maize, pulses, roots and tuber, oil crops) and the actual availability of land for crop production. }\end{array}$ \\
\hline IAP & Timber production (Mt/year) & Timber production from managed forests. \\
\hline IAP & $\begin{array}{l}\text { Water Exploitation Index (WEI) } \\
\quad \text { (remaining water >WEI 0.4) }\end{array}$ & $\begin{array}{l}\text { Water availability is modelled taking into consideration agricultural, industrial and domestic demand } \\
\text { on the water resource and then compared with a threshold at which severe water stress is expected. } \\
\text { (i.e. > WEI 0.4) (40\% ratio between water availability and water use) (Alcamo et al. 2007). } \\
\text { Negative numbers indicate threshold exceedance. }\end{array}$ \\
\hline \multicolumn{3}{|c|}{ Regulating services } \\
\hline $\mathrm{I}-\mathrm{G}$ & $\begin{array}{l}\text { Pest control (\% of cropland sufficiently } \\
\text { protected) }\end{array}$ & $\begin{array}{l}\text { Pest control services are defined by the predation rate in cropland areas. This rate is calculated based } \\
\text { on the relationship between the percentage of pests killed and the percentage of natural vegetation } \\
\text { within grid cell. The service is considered present when the predation rate is above a threshold at } \\
\text { which pest control can be effective (>36\%) (Hawkins and Cornell 1994). }\end{array}$ \\
\hline $\mathrm{I}-\mathrm{G}$ & $\begin{array}{l}\text { Soil erosion protection (\% area with low } \\
\text { soil erosion risk) }\end{array}$ & $\begin{array}{l}\text { Soil erosion protection is expressed as the area of erosion-sensitive land use (i.e. cropland, urban } \\
\text { areas, managed grassland) that is sufficiently protected against soil erosion by the presence of } \\
\text { vegetation. Erosion protection is delivered sufficiently when soil erosion risk is low to moderate } \\
\text { (<0.30 Erosion Index following Hootsmans et al. 2001). The erosion risk is calculated as a } \\
\text { function of soil and landscape characteristics (i.e. elevation, LULC) and rainfall intensity } \\
\text { following the Universal Soil Loss Equation (USLE) (Batjes 1996). }\end{array}$ \\
\hline $\mathrm{I}-\mathrm{G}$ & Carbon sequestration (ton C/year) & $\begin{array}{l}\text { The net ecosystem productivity (NEP) is used as a proxy of } \mathrm{CO}_{2} \text { sequestration by vegetation. The } \\
\text { NEP is defined by the difference between net primary productivity (NPP) of terrestrial ecosystems } \\
\text { and soil respiration. }\end{array}$ \\
\hline IAP & Carbon sequestration (ton C/year) & $\begin{array}{l}\text { Total carbon stored in biomass of areas under intensive agriculture, extensive agriculture, forests and } \\
\text { unmanaged land. }\end{array}$ \\
\hline \multicolumn{3}{|c|}{ Biodiversity } \\
\hline $\mathrm{I}-\mathrm{G}$ & $\begin{array}{l}\text { Mean species abundance (MSA) } \\
\quad(\text { dimensionless } 0-1)\end{array}$ & $\begin{array}{l}\text { The MSA represents the mean abundance of original species compared to their mean abundance in } \\
\text { an undisturbed reference situation. The MSA is calculated based on quantitative relationships with } \\
\text { several pressure variables (including temperature change, nitrogen deposition, land use) } \\
\text { established based on meta-analyses of literature data (Alkemade et al. 2009; Schipper et al. 2016). }\end{array}$ \\
\hline IAP & $\begin{array}{l}\text { Species habitat suitability index (SHSI) } \\
\quad \text { (\# grid cells) }\end{array}$ & $\begin{array}{l}\text { The SHSI is based on habitat suitability modelling for } 107 \text { species. A grid cell contributes to the } \\
\text { available habitat if } 5 \% \text { of the cell contains an appropriate climate and land use. Land set aside for } \\
\text { biodiversity contributes to the available habitat. The index is calculated as the total number of grid } \\
\text { cells with suitable climate and habitat for each species and divided by the total number of species. } \\
\text { Arable, Forest and Heath indicators are subsets of the total species indicator. }\end{array}$ \\
\hline
\end{tabular}

I- $G$, IMAGE-GLOBIO model; IAP, CLIMSAVE IAP model

\section{Results}

\section{Future changes in biodiversity and ecosystem services at the European scale}

The sectoral, technology-focussed UWS scenario projected a strong decline in cropland and a consequent expansion of forest areas (Fig. 1). The cropland decline reflects a combination of decreasing food demands (diet change), a significant increase in production efficiency due to technological development, and an increase in imports of agricultural products due to liberal trade policy. Food production within Europe was projected to increase in IMAGE-GLOBIO, due to agricultural intensification, but decrease in the CLIMSAVE IAP as a result of increased imports reducing demand for food produced within Europe. As a result of the LULC changes, increases were projected for wild food and timber provision as well as regulating ES, such as pest control, soil erosion control and to some extent carbon sequestration. For biodiversity, IMAGE-GLOBIO projected a decrease in MSA values in 
spite of an increase in (semi-)natural habitats (i.e. forest and grasslands), reflecting the influence of climate change. The CLIMSAVE IAP projected a decrease in the overall SHSI, primarily driven by a decline in farmland habitats, but saw an increase in the forest SHSI due to increases in forest areas.

The import-restricted, wealth-focussed WB scenario revealed similar LULC changes to UWS (i.e. less cropland and more forest), but changes were less pronounced (Fig. 1). This reflects that WB is characterised by higher food demands within Europe due to increases in population size and preferences for meat, and lower levels of international trade. Furthermore, timber provision was highest in WB, reflecting technological efficiency and reforestation of abandoned croplands. Water availability, however, was projected to decline, despite water-saving technology and increased irrigation efficiency. Pest control and soil erosion regulation were projected to increase, facilitated by the conversion of abandoned cropland areas into (semi-)natural habitats such as forest and grassland. However, the level of soil erosion risk was high (i.e. a relatively small increase in erosion control when compared to the base year) due to severe climate change, resulting in more extreme events. Carbon sequestration was projected to decline
(IMAGE-GLOBIO) or show no change when compared to the base year (CLIMSAVE IAP), whilst biodiversity was projected to decline, both in IMAGE-GLOBIO and the CLIMSAVE IAP.

In the EU-coordinated, BES-focused EC scenario, IMAGE-GLOBIO projected an increase in forests and grasslands as a result of a decline in cropland areas (Fig. 1). Despite this decline, there was no change in overall food provision due to technological developments within the agricultural sector, population decline and dietary change (i.e. increased vegetarianism). In contrast, CLIMSAVE IAP showed an increase in cropland area and food production, despite the changes in diet, driven by a decrease in EU food imports alongside the lower level of agricultural intensification than in the UWS and WB scenarios. Timber, water provision and wild food availability showed little change whilst regulating services such as pest control and soil erosion control showed moderate increases. Carbon sequestration showed a strong (IMAGE-GLOBIO) to moderate (CLIMSAVE IAP) decline. In IMAGE-GLOBIO, biodiversity values declined to similar levels as in UWS, in spite of an increase in protected areas (Table S2). In CLIMSAVE IAP, biodiversity showed no net overall change,

\begin{tabular}{|c|c|c|c|c|c|}
\hline Model & Indicator (unit) & UWS & WB & $\mathrm{EC}$ & RR \\
\hline \multicolumn{6}{|c|}{ Land Use / Land Cover (LULC) Indicators } \\
\hline $\mathrm{I}-\mathrm{G}$ & Cropland area $\left(\mathrm{km}^{2}\right)$ & --- & - & - - & -- \\
\hline IAP & Cropland area $\left(\mathrm{km}^{2}\right)$ & $-\cdots$ & & ++ & ++ \\
\hline $\mathrm{I}-\mathrm{G}$ & Forest area $\left(\mathrm{km}^{2}\right)$ & ++ & + & + & + \\
\hline IAP & Forest area $\left(\mathrm{km}^{2}\right)$ & +++ & ++ & & -- \\
\hline I-G & Grassland area $\left(\mathrm{km}^{2}\right)$ & + & + & + & \\
\hline IAP & Grassland area $\left(\mathrm{km}^{2}\right)$ & --- & -- & - & \\
\hline \multicolumn{6}{|c|}{ Provisioning Service Indicators } \\
\hline $\mathrm{I}-\mathrm{G}$ & Food crop production (ton fresh weight/year) & + & ++ & & - - \\
\hline IAP & Food crop production (ton fresh weight/year) & -- & +++ & +++ & ++ \\
\hline $\mathrm{I}-\mathrm{G}$ & Wild food availability (M ton/year) & + & + & & \\
\hline IAP & Timber provision (Mt/year) & + & ++ & & - - \\
\hline IAP & Water provision (remaining water $>$ WEI 0.4 ) & & - & & \\
\hline \multicolumn{6}{|c|}{ Regulating Service Indicators } \\
\hline $\mathrm{I}-\mathrm{G}$ & Pest control (\% of cropland sufficiently served by services) & +++ & ++ & ++ & ++ \\
\hline $\mathrm{I}-\mathrm{G}$ & Soil erosion control (\% area with low soil erosion risk) & ++ & + & ++ & + \\
\hline I-G & Carbon sequestration (NEP) (ton C/year) & --- & $-\cdots$ & $-\cdots$ & $-\cdots$ \\
\hline IAP & Carbon sequestration (ton C/year) & +++ & & -- & $-\ldots$ \\
\hline \multicolumn{6}{|c|}{ Biodiversity Indicators } \\
\hline $\mathrm{I}-\mathrm{G}$ & Mean Species Abundance (dimensionless) & -- & -- & -- & -- \\
\hline IAP & Species habitat suitability Index (all habitats) (\# grid cell) & - & -- & & - \\
\hline IAP & Species habitat suitability Index (arable habitats) (\# grid cell) & $-\cdots$ & -- & - & - \\
\hline IAP & Species habitat suitability Index (forest habitats) (\# grid cell) & ++ & - & + & -- \\
\hline IAP & Species habitat suitability Index (heathland habitats) (\# grid cell) & -- & -- & + & + \\
\hline
\end{tabular}

Fig. 1 Changes in future land use/land cover, biodiversity and ecosystem service indicators. Symbols indicate the direction of change relative to the baseline year (2010) and the number of symbols reflects the magnitude of the change, where $+/-$ represents $>5 \%,++/-$ represents $5-10 \%$ and
+++--- represents $10-25 \%$ change. Blank cells indicate no change within -5 to $+5 \%$ relative to the baseline. Model: $I-G=$ IMAGEGLOBIO; IAP = CLIMSAVE IAP 
with small declines in SHSI for cereal field margin species and improvements for forest and heathland species, as a result of relatively moderate changes in LULC and efforts to integrate land for nature within agricultural land.

Both LULC change and underlying drivers showed similar patterns in the localism-driven, cross-sectoral $R R$ scenario as in the EC scenario. Cropland areas and food production increased in CLIMSAVE IAP, whilst both decreased in IMAGE-GLOBIO (Fig. 1). Changes in food provision, however, were lower in RR in IMAGE-GLOBIO reflecting lower food demands as a result of a significant shift towards vegetarianism and population decline. Under CLIMSAVE IAP, the increased vegetarianism and population decline are however not sufficient to compensate for the decrease in agricultural technology and the steep decline in food imports, which necessitates agricultural expansion to increase the amount of food produced within Europe to meet local demand. With respect to regulating ES, pest control and soil erosion control increased. Erosion control showed a relatively small increase when compared to the base year due to the higher service demand (i.e. more cropland) and more severe climate change. In contrast, timber and carbon sequestration were projected to decline strongly, reflecting deforestation in the CLIMSAVE IAP and climate-induced increases in soil respiration in IMAGE-GLOBIO. Despite low levels of water-saving technology, there were no major changes in water provisioning. Changes in SHSI were similar to those observed for the EC scenario with an increase in the heathland SHSI due to efforts to set aside land for habitat conservation (such as heathland habitat). However, additional pressures from forest loss led to a lower overall SHSI value. IMAGE-GLOBIO's MSA values declined, to a slightly greater extent when compared to the EC scenario (Table S2).

\section{Understanding differences between models}

The models produced similar output variables for three sets of indicators which enable direct comparison: (i) three LULC indicators (i.e. cropland, forest and grassland area), (ii) two ES indicators (i.e. food crop production and climate regulation) and (iii) two biodiversity indices (i.e. MSA and SHSI). Although the two models largely agreed on the areas of cropland, forest and grassland estimated for the base year 2010 (Fig. S1), projected future LULC changes were mostly smaller in IMAGE-GLOBIO than the CLIMSAVE IAP (Fig. 2). Furthermore, the changes in LULC projected by IMAGEGLOBIO were more similar across the four scenarios, with all four scenarios resulting in decreases in cropland, increases in forest and increases in grasslands. Projections from the CLIMSAVE IAP showed considerably more variability across the scenarios, with cropland increase and forest decrease in some scenarios (EC, RR) but vice versa in others
(UWS, WB). Grassland generally decreased in all scenarios apart from a small increase in RR (Fig. 2).

Differences in the LULC changes projected by the two models reflect differences in land use allocation as well as differences in settings related to international trade. CLIMSAVE IAP allocates land which is not needed for agricultural purposes primarily to forest (Fig. 2a and c), defined by the net primary productivity (NPP) - if the NPP is positive and greater than the grass yield of extensive grass, the land is allocated to forest, else grassland (Audsley et al. 2015). In contrast, IMAGE-GLOBIO replaces abandoned cropland by natural land cover (i.e. forest or grassland) according to the proportion of land cover types present in that grid cell under baseline conditions (Schipper et al. 2016). A second key difference relates to the representation of trade. In IMAGEGLOBIO, croplands decline when European food demands can be met by international imports, whilst in the CLIMSAVE IAP, food imports to Europe are part of the scenario settings and agricultural demands that are not met by imports have to be fulfilled within Europe, leading to the expansion of cropland areas (Fig. 2b and d). IMAGEGLOBIO's food imports to Europe were estimated based on international food production and intercontinental trade dynamics driven by the overarching SSP scenarios, which ensures that commodities are produced in line with demand and supply on the global market, allowing cropland areas to decline even in the most strongly constrained international trade scenario (Fig. 2d). These boundary conditions drive the magnitude of LULC change within Europe. In contrast, the CLIMSAVE IAP defines food imports to Europe as part of the iterative process between scenario developers and modelling teams to represent the scenario storyline as closely as possible. Hence, if food imports decrease in the scenario (i.e. WB, EC and RR), then more food has to be produced within Europe to meet local demand, either through an increase in technological development (i.e. WB) or by an expansion of cropland areas (i.e. EC and RR). Conversely, if food imports to Europe increase in the scenario (i.e. UWS), then this releases land for other purposes, such as forestry, and resulting land use coverages (i.e. percentage areas) tend to be more similar to those modelled by IMAGE-GLOBIO (e.g. UWS) (Fig. 2a).

With regard to ecosystem services, the two models agree on the total food crop production in the base year 2010 (IMAGE-GLOBIO: 736 million ton; CLIMSAVE IAP: 792 million ton). However, the models differ in their future projections, reflecting differences in models' settings regarding international trade, as discussed above. As a result, the scenarios with trade restrictions (i.e. WB, EC and RR) project larger food crop production in the CLIMSAVE IAP than in IMAGEGLOBIO (Table S2). With regard to carbon sequestration, the two models differ in the projected total amount of carbon sequestered and in the direction of change. In IMAGE- 
Fig. 2 Future land use / land cover (i.e. urban, cropland, forest, grassland) distribution and its relative change projected by the two models for the four scenarios a) United-We-Stand, b) EcoCentre, $\mathbf{c})$ Wealth-Being and d) Rural Revival
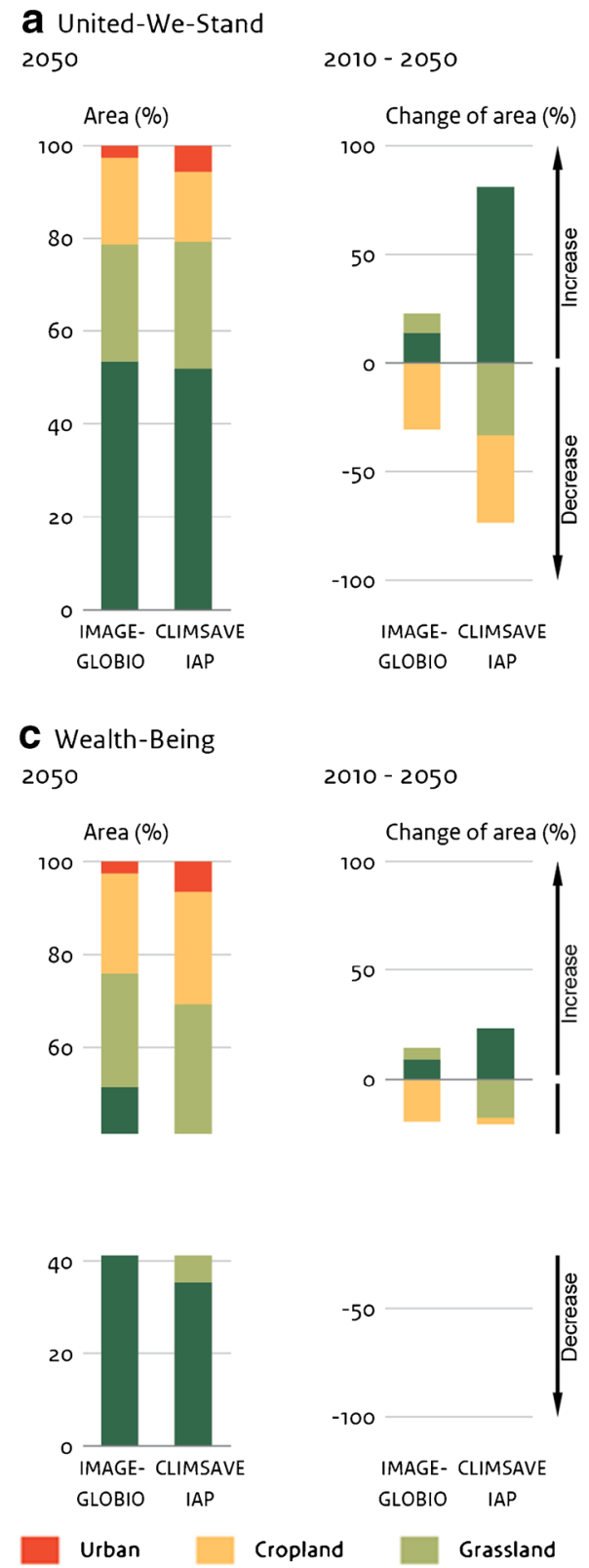

b Eco-Centre
2050

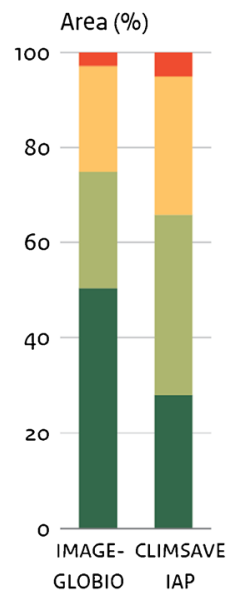

d Rural-Revival 2050
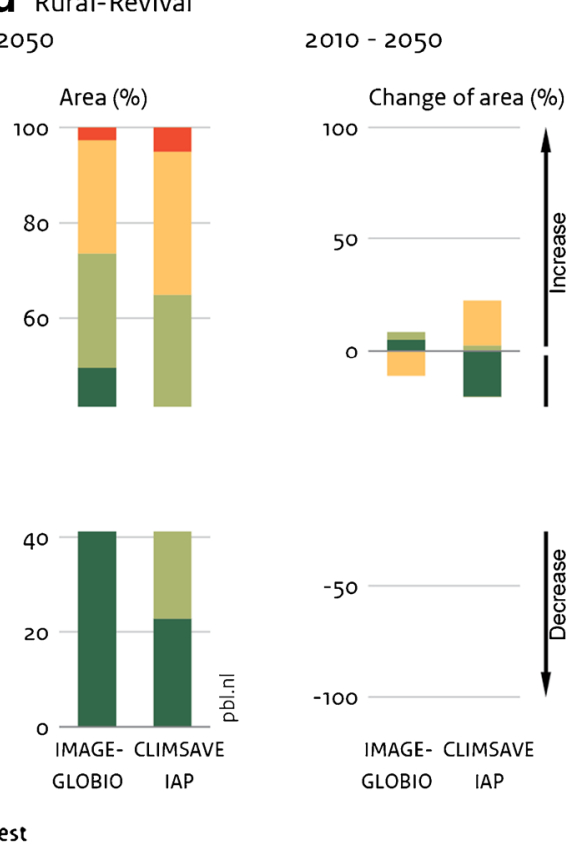

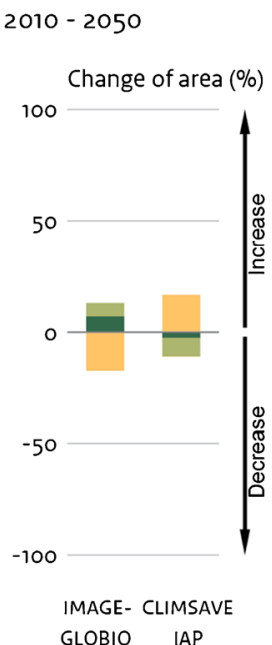

GLOBIO IAP

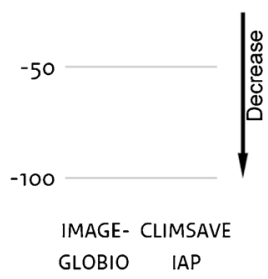

GLOBIO, carbon sequestration is a function of both land cover (such as forest) and climate. Increases in temperature and atmospheric $\mathrm{CO}_{2}$ concentrations induced by climate change are assumed to enhance plant growth, resulting in increased carbon uptake by plants in the most severe climate change scenarios. However, soil carbon losses also increase with warming, which may offset or even decrease net carbon sequestration (Schröter et al. 2005; Zaehle et al. 2007). As a result, climate regulation services are projected to decline in all four scenarios in IMAGE-GLOBIO, although the decline is lower in the more extreme climate change scenarios (Table S1 and S2). In CLIMSAVE IAP, climate regulation services are primarily driven by changes in forest carbon stocks, so scenarios that project increases in forest areas (i.e. UWS and WB) result in higher carbon storage values.
Whilst the biodiversity metrics used by the two IAMs highlight a different aspect of biodiversity, both indices project a further decline of biodiversity (Fig. 1) despite increases in (semi-)natural habitats (i.e. forest and grasslands) (UWS, and to some extent WB) and/or increases in protected areas and agricultural land set aside for nature development (EC and RR). MSA values in IMAGE-GLOBIO showed only declines, with the largest decline in the scenario with the largest global mean temperature increase (i.e. WB) (Table S1). This may reflect that MSA - which can only decrease in response to warming (Nunez et al. 2019; Schipper et al. 2020) - shows a stronger response to climate change than to LULC change in the scenario analysed. Conversely, CLIMSAVE IAP's SHSI values showed more variable outcomes, including declines as well as increases, which may reflect that LULC was more 
prominent in CLIMSAVE IAP than in IMAGE-GLOBIO (Fig. 2). In line with this, we found the greatest change in biodiversity occurring in the scenarios with the greatest LULC changes (i.e. WB and UWS). In addition, the breakdown of species by habitat preferences in CLIMSAVE IAP results in a more diverging biodiversity response. For example, farmland species and heathland species were better off in RR and EC, whilst forest species were projected to benefit in UWS and EC.

\section{Discussion}

\section{Future developments of biodiversity and ecosystem services in Europe}

Our projections of four future socio-environmental scenarios indicate that climate and land use change will continue to pose significant threats to biodiversity and some ES. Although targeted policies (e.g. on climate change, biodiversity conservation and sustainable land management) and behavioural change (e.g. reduced meat consumption, water-saving behaviour) reduced the extent of BES changes, none of the four scenarios achieved overall preservation of BES in Europe. Against the backdrop of recent developments in the European and global biodiversity policy arenas (e.g. the EU biodiversity strategy, CBD post-2020 biodiversity strategy), our results thus stress the message that achieving European and global biodiversity goals requires ambitious actions and policies, including the expansion of protected areas as well as measures which go beyond traditional area-based conservation. There are two main explanations why the scenarios simulated here were insufficient to counteract overall BES decline: (i) the magnitude of change in the factors limiting the decline in BES (i.e. conservation measures, technological development within the agricultural sector, climate change mitigation, reduced food demand) was too low, and (ii) trade-offs between BES occurred (i.e. improvements in one aspect of BES resulting in losses in another) due to complex interdependencies within human and environmental systems.

As our scenarios were exploratory rather than targetseeking (Pichs-Madruga et al. 2016), conservation measures were defined that were consistent with the scenario assumptions rather than tuned to meet predefined BES targets. Although a coherent portfolio of conservation measures was implemented in the EC scenario (e.g. land set aside, expanding protected areas or reducing meat consumption; Table 1), even this scenario fell short in halting or reversing the downward trend in biodiversity loss by 2050 . In this respect, our model projections may help to identify the most effective measures and strategies. We found, for example, that technological development, such as the promotion of watersaving technologies, improved and more efficient irrigation technology, agricultural mechanisation and improving agricultural yield, can play a key role. Especially the further increase in yields (i.e. production per unit area), as illustrated by ongoing increases in agricultural productivity in Europe (Schils et al. 2018), reduces the demand for agricultural land. When undertaken sustainably, this in turn offers opportunities for the restoration of (semi-)natural habitats, benefiting associated biodiversity (e.g. forest species) and ES (e.g. soil erosion, pest control), as illustrated by the UWS and WB scenarios. Conversely, minimal technological use (as illustrated by RR) necessitates increases in cropland area with considerable impacts on BES if food demands cannot be met by imports. Attempting sustainable agricultural intensification, as illustrated by the EC scenario, resulted in the least overall land use change in both models, helping to minimise habitat loss. These findings are in agreement with Kok et al. (2018), who demonstrated that achieving global biodiversity targets (i.e. halting loss of biodiversity) requires considerable changes in land management practices by different sectors. These changes may include the implementation of sustainable forestry practices, such as reduced impact logging, or more sustainable or ecological intensification of the agricultural sector, for example by intercropping, agroforestry, resource efficiency or intertwining agricultural landscapes with natural elements or corridors. Agri-environmental schemes, such as providing subsidies to farmers to set aside productive land for biodiversity conservation (e.g. extensive grasslands, field margin strips), have been shown to be an important policy instrument to protect European biodiversity in agricultural landscapes (Kleijn and Sutherland 2003; Van Buskirk and Willi 2004). The CLIMSAVE IAP model underlines this potential as projections illustrate that setting aside productive land for other habitats leads to lower loss of non-arable species (as illustrated by EC when compared to other scenarios). We note that neither of the two models is sufficiently detailed in the differentiation of land use categories to address the benefits and tradeoffs of subtle differences in land management practices. The broad categorisation of land use/management in terms of intensive versus extensive agriculture does not allow the effects of agroforestry, silvopasture or organic farming, for example, to be analysed pointing at a need for future research within BES scenario development and modelling.

Our results further indicate that behavioural change (e.g. reducing food demand through dietary change), as exemplified by RR and EC, can play a key role in avoiding future loss of BES. This is in line with previous studies showing that changes in consumption patterns (e.g. reduction in (food) waste, limiting the per capita intake of animal products) reduce land demand and conversion (Stehfest et al. 2009; Willett et al. 2019) and illustrates a critical pathway to safe future BES (Chan et al. 2019; Erb et al. 2016; Kok et al. 2018; Rondinini and Visconti 2015; Visconti et al. 2016). Results from the CLIMSAVE IAP model highlight the importance of 
dietary changes in influencing LULC and BES change, but show that other factors also need to be considered within a policy mix for this to be effective. For example, in both EC and RR, trade restrictions on food imports were found to drive increases in cropland and food provision despite quite significant changes in dietary preference. Moreover, diet changes alone might be insufficient to reduce future climate change, which may pose an increasingly important additional threat to biodiversity. The projections from IMAGE-GLOBIO revealed climate change-induced biodiversity loss in all scenarios (Table S1 and Table S2), emphasising the relevance of climate policy for meeting global and European biodiversity targets, such as those in the EU post-2020 biodiversity strategy (Hof et al. 2018; IPBES 2019; IPCC 2019).

Trade-offs among BES provide a second explanation as to why none of our scenarios was beneficial overall. Trade-offs among BES are common (Harmáčková and Vačkář 2015; Mouchet et al. 2017; Schulp et al. 2016) and highly dependent on management choices (Bennett et al. 2009; Rodríguez et al. 2006). A common trade-off is the increase in provisioning services at the expense of regulating and supporting services (incl. biodiversity), which was especially prominent in the economic wealth-focussed WB scenario. This trade-off was less pronounced in scenarios with more sustainability objectives (e.g. mitigation of climate change, reduced meat consumption, nature conservation measures), as illustrated by the EC and UWS scenarios. Trade-offs between BES may also occur in space (Rodríguez et al. 2006). In our study, the promotion of coordinated international trade allowed cropland areas in Europe to decline without compromising European food security. Abandoned cropland can then be used for restoration or rewilding, with potential benefits for BES in Europe (Navarro and Pereira 2015; Török et al. 2011). Agrienvironment schemes may provide another opportunity to maintain biodiversity especially in agricultural marginal areas (Kleijn and Sutherland 2003; Van Buskirk and Willi 2004). Yet, enhanced imports of food may result in the loss of biodiversity and degradation of ES elsewhere in the world, due to replacement of natural habitat by agricultural land (Schröter et al. 2018; Steen-Olsen et al. 2012; Wilting et al. 2017). Wilting et al. (2017), for example, have shown that the share of foreign biodiversity loss in countries' biodiversity footprints was much higher for countries with high imports than in countries that are more self-sufficient in producing food products and other consumer goods. With respect to global sustainability goals, it is important to consider these off-site effects (also labelled footprints, tele-coupling, teleconnections, interregional flows, depending on the context), which are, so far, mostly neglected in BES assessments (Lautenbach et al. 2019; Schröter et al. 2018). Whilst including these effects was beyond the scope of our study, we acknowledge the need for future research to incorporate imported biodiversity loss in scenario projections.

\section{Model intercomparison}

The model intercomparison highlighted different sources of uncertainty related to differences in model structure and parameterisation. We revealed major uncertainties related to the different land use allocation approaches, similar to other model comparison studies (Alexander et al. 2017; Prestele et al. 2016; Schmitz et al. 2014). Furthermore, we identified important differences in driving forces behind BES changes, particularly whether climate or LULC change is considered the major driver of carbon sequestration, either of which is commonly assumed (Schulp et al. 2008; Zaehle et al. 2007). Another source of uncertainty comprised the differences in spatial extent and boundary conditions, resulting in greater heterogeneity in LULC projections by the European CLIMSAVE IAP model. Similarly, differences in boundary conditions regarding international trade resulted in different estimates of future European food production, with larger differences between scenarios for CLIMSAVE IAP. Differences in model results related to different trade assumptions (e.g. self-sufficiency approach or trade responsive approach) have also been demonstrated by Schmitz et al. (2014).

In addition to the differences in model structure, there were also differences in scenario parameterisation. Although the model input was harmonised as much as possible within the scenarios, there were differences induced by different boundary conditions inherent to the IAMs. The CLIMSAVE IAP is designed for European-scale analyses with stakeholders, hence can be easily configured to match scenario assumptions. In contrast, the IMAGE-GLOBIO model is designed for global-scale analyses, and it was decided that the European parameterisation should match a plausible global context as derived from the global SSP scenarios. As a result, differences in key drivers between scenarios, such as human population changes, were mostly less pronounced in the IMAGEGLOBIO parameterisation (Table S1). For some of the indicators and scenarios, differences in model structure and parameterisation resulted in different magnitude and direction of change (e.g. the biodiversity indicators in the UWS scenario; Fig. 1), highlighting the added value of using multiple complementary models in order to provide nuanced and contextualised insights.

As modelling approaches to quantify BES are diverse (Bagstad et al. 2013; Brotons et al. 2016; Crossman et al. 2013; Martínez-Harms and Balvanera 2012; Rockström et al. 2009), some have called for a standardised methodological approach or blueprint for modelling (Crossman et al. 2013; Martínez-Harms and Balvanera 2012) and efforts have been taken to harmonise input data and definitions (Hurtt et al. 2011; Kim et al. 2018). However, others argue that standardisation may provide false certainty in projections (Alexander et al. 2017), whereas transparency about sources and magnitude of model uncertainties is a prerequisite for 
robust model inference and decision-making (Volk 2013). Furthermore, our study illustrated that the use of multiple models allows additional or complementary dimensions of BES to be quantified, thus providing a more comprehensive and inclusive picture of alternative plausible futures. For example, biodiversity in IMAGE-GLOBIO is represented by an indicator of overall intactness, whereas CLIMSAVE IAP focuses on the species level and allows winners and losers to be distinguished. Multi-modelling approaches have been widely adopted within climate change assessment to better support climate policy formulation (i.e. IPCC) (Meehl et al. 2007). Some first attempts to apply such approaches in BES assessments are underway (Kim et al. 2018; Thuiller et al. 2019), but need to be adopted more routinely to better inform international biodiversity policy. Multi-modelling and probabilistic approaches would not only allow for more systematic quantification of uncertainties stemming from different sources (e.g. model uncertainty, parameter uncertainty), but also a broader set of relevant indicators of BES, including additional dimensions of biodiversity and benefits to people, to be quantified.

\section{Conclusion}

We used two IAMs to assess the consequences for BES in Europe under four future socio-environmental scenarios. Despite differences in model structure and parameterisation, the different models project similar trends in future BES, consistent with the scenarios. In all scenarios, climate and land use change were projected to pose significant threats to biodiversity and some ecosystem services. Yet, the magnitude of biodiversity loss can be reduced, and the provisioning of multiple ES enhanced by addressing climate change, reducing the pressure on the food system (e.g. through dietary change, sustainable technological improvements) and through nature conservation measures (e.g. protected areas, land set aside for nature). Our study highlights the necessity of more ambitious policy and actions if future BES in Europe are to be safeguarded, whilst accounting for inevitable trade-offs, particularly between provisioning and other services. Multimodelling approaches provide a valuable tool for enabling more comprehensive analyses and accounting for uncertainties, both of which are critical to progress assessments in support of better BES policy-making.

Acknowledgements We would like to thank Jennifer Hauck for the helpful discussion on scenario analysis and comments on an earlier version of this paper, and Sandy van Tol for developing the figures. We also thank two anonymous reviewers and the handling editor for giving valuable suggestions to improve the paper.

Funding information This research was funded by the European Commission Seventh Framework Programme under Grant Agreement No. 244031 (The CLIMSAVE Project; Climate change integrated assessment methodology for cross-sectoral adaptation and vulnerability in Europe; www.climsave.eu), No. 308428 (The OpenNESS project;
Operationalisation of natural capital and ecosystem services: from concepts to real-world applications) and No. 603416 (The IMPRESSIONS project; Impacts and risks from higher-end scenarios: strategies for innovative solutions).

Open Access This article is licensed under a Creative Commons Attribution 4.0 International License, which permits use, sharing, adaptation, distribution and reproduction in any medium or format, as long as you give appropriate credit to the original author(s) and the source, provide a link to the Creative Commons licence, and indicate if changes were made. The images or other third party material in this article are included in the article's Creative Commons licence, unless indicated otherwise in a credit line to the material. If material is not included in the article's Creative Commons licence and your intended use is not permitted by statutory regulation or exceeds the permitted use, you will need to obtain permission directly from the copyright holder. To view a copy of this licence, visit http://creativecommons.org/licenses/by/4.0/.

\section{References}

Alcamo J, van Vuuren D, Ringler C, Cramer W, Masui T, Alder J, Schulze K (2005) Changes in nature's balance sheet: model-based estimates of future worldwide ecosystem services. Ecol Soc 10

Alcamo J, Flörke M, Märker M (2007) Future long-term changes in global water resources driven by socio-economic and climatic changes. Hydrolog Sci J 52:247-275. https://doi.org/10.1623/hysj. 52.2.247

Alexander P, Prestele R, Verburg PH, Arneth A, Baranzelli C, Batista e Silva F, Brown C, Butler A, Calvin K, Dendoncker N (2017) Assessing uncertainties in land cover projections. Glob Chang Biol 23:767-781. https://doi.org/10.1111/gcb.13447

Alkemade R, van Oorschot M, Miles L, Nellemann C, Bakkenes M, ten Brink B (2009) GLOBIO3: a framework to investigate options for reducing global terrestrial biodiversity loss. Ecosystems 12:374 390. https://doi.org/10.1007/s10021-009-9229-5

Audsley E, Trnka M, Sabaté S, Maspons J, Sanchez A, Sandars D, Balek J, Pearn K (2015) Interactively modelling land profitability to estimate European agricultural and forest land use under future scenarios of climate, socio-economics and adaptation. Clim Chang 128: 215-227. https://doi.org/10.1007/s10584-014-1164-6

Bagstad KJ, Semmens DJ, Winthrop R (2013) Comparing approaches to spatially explicit ecosystem service modeling: a case study from the San Pedro River, Arizona. Ecosyst Serv 5:40-50. https://doi.org/10. 1016/j.ecoser.2013.07.007

Batjes N (1996) Global assessment of land vulnerability to water erosion on a $1 / 2$ by $1 / 2$ grid. Land Degrad Dev 7:353-365. https://doi.org/10. 1002/(SICI)1099-145X(199612)7:4\%3C353::AID-LDR239\%3E3. $0 . \mathrm{CO} ; 2-\mathrm{N}$

Bennett EM, Peterson GD, Gordon LJ (2009) Understanding relationships among multiple ecosystem services. Ecol Lett 12:13941404. https://doi.org/10.1111/j.1461-0248.2009.01387.x

Brotons L, Christensen V, Ravindranath NH, Cao M, Chun JH, Maury O, Peri PL, Proença V, Salihoglu B (2016) Modelling impacts of drivers on biodiversity and ecosystems. Chapter 5 in IPBES (2016): the methodological assessment report on scenarios and models of biodiversity and ecosystem services. In: Ferrier S, Ninan KN, Leadley P, Alkemade R, Acosta LA, Akçakaya HR, Brotons L, Cheung WWL, Christensen V, Harhash KA, KabuboMariara J, Lundquist C, Obersteiner M, Pereira HM, Peterson G, Pichs-Madruga R, Ravindranath N, Rondinini C, Wintle BA (eds) Secretariat of the Intergovernmental Science-Policy Platform for Biodiversity and Ecosystem Services, Bonn 
CBD (2010) Aichi biodiveristy targets. http://www.cbd.int/sp/targets/. Accessed 10 June 2019

Chan KMA, Agard J, Liu J, de Aguiar PD, Armenteras D, Boedhihartono AK, Cheung WWL, Hashimoto S, Hernández Pedraza GC, Hickler H, Jetzkowitz J, Kok M, Murray-Hudson M, O'Farrell P, Satterfield T, Saysel AK, Seppelt R, Strassburg B, Xue D (2019) Pathways towards a sustainable future. Chapter 5 in IPBES 2019: global assessment on biodiversity and ecosystem services. In: Brondízio ES, Díaz S, Settele J, Ngo HT (eds) Secretariat of the Intergovernmental Science-Policy Platform for Biodiversity and Ecosystem Services, Bonn

Cheung WWL, Rondinini C, Avtar R, van den Belt M, Hickler T, Metzger JP, Scharlemann JPW, Velez-Liendo X, Yue TX (2016) Linking and harmonizing scenarios and models across scales and domains. Chapter 6 in IPBES (2016): the methodological assessment report on scenarios and models of biodiversity and ecosystem services. In: Ferrier S, Ninan KN, Leadley P, Alkemade R, Acosta LA, Akçakaya HR, Brotons L, Cheung WWL, Christensen V, Harhash KA, Kabubo-Mariara J, Lundquist C, Obersteiner M, Pereira HM, Peterson G, Pichs-Madruga R, Ravindranath N, Rondinini C, Wintle BA (eds) Secretariat of the Intergovernmental Science-Policy Platform for Biodiversity and Ecosystem Services, Bonn

CLC (2000) CORINE Land Cover 2000 raster data. European Environmental Agency, Copenhagen

Crossman ND, Burkhard B, Nedkov S, Willemen L, Petz K, Palomo I, Drakou EG, Martín-Lopez B, Phearson T, Boyanova K (2013) A blueprint for mapping and modelling ecosystem services. Ecosyst Serv 4:4-14. https://doi.org/10.1016/j.ecoser.2013.02.001

Dunford RW, Smith AC, Harrison PA, Hanganu D (2015) Ecosystem service provision in a changing Europe: adapting to the impacts of combined climate and socio-economic change. Landsc Ecol 30: 443-461. https://doi.org/10.1007/s10980-014-0148-2

EC (2011) Our life insurance, our natural capital: an EU biodiversity strategy to 2020. Communication from the Commission to the European Parliament, the Council, the European Economic and Social Committee and the Committee of the Regions. European Commission, Brussels

EC (2020) Bringing nature back into our lives: EU Biodiversity Strategy for 2030. Communication from the Commission to the European Parliament, the Council, the European Economic and Social Committee and the Committee of the Regions. European Commission, Brussels

Erb K-H, Lauk C, Kastner T, Mayer A, Theurl MC, Haberl H (2016) Exploring the biophysical option space for feeding the world without deforestation. Nat Commun 7:11382. https://doi.org/10.1038/ ncomms 11382

Ferrier S, Ninan KN, Leadley P, Alkemade R, Kolomytsev GO, Moraes RM, Mohammed EY, Trisurat Y (2016) Overview and vision. Chapter 1 in IPBES (2016): the methodological assessment report on scenarios and models of biodiversity and ecosystem services. In: Ferrier S, Ninan KN, Leadley P, Alkemade R, Acosta LA, Akçakaya HR, Brotons L, Cheung WWL, Christensen V, Harhash KA, Kabubo-Mariara J, Lundquist C, Obersteiner M, Pereira HM, Peterson G, Pichs-Madruga R, Ravindranath N, Rondinini C, Wintle BA (eds) Secretariat of the Intergovernmental Science-Policy Platform on Biodiversity and Ecosystem Services, Bonn

Harfoot M, Tittensor DP, Newbold T, McInerny G, Smith MJ, Scharlemann JPW (2014) Integrated assessment models for ecologists: the present and the future. Glob Ecol Biogeogr 23:124-143. https://doi.org/10.1111/geb.12100

Harmáčková ZV, Vačkář D (2015) Modelling regulating ecosystem services trade-offs across landscape scenarios in Třeboňsko Wetlands Biosphere Reserve, Czech Republic. Ecol Model 295:207-215. https://doi.org/10.1016/j.ecolmodel.2014.10.003
Harrison PA, Holman I, Berry P (2015) Assessing cross-sectoral climate change impacts, vulnerability and adaptation: an introduction to the CLIMSAVE project. Clim Chang 128:153-167. https://doi.org/10. 1007/s10584-015-1324-3

Harrison PA, Dunford RW, Holman IP, Rounsevell MD (2016) Climate change impact modelling needs to include cross-sectoral interactions. Nat Clim Chang 6:885-890. https://doi.org/10.1038/ nclimate3039

Harrison PA, Hauck J, Austrheim G, Brotons L, Cantele M, Claudet J, Fürst C, Guisan A, Harmáčková ZV, Lavorel S, Olsson GA, Proença V, Rixen C, Santos-Martín F, Schlaepfer M, Solidoro C, Takenov Z, Turok J (2018) Current and future interactions between nature and society. Chapter 5 in IPBES (2018): the IPBES regional assessment report on biodiversity and ecosystem services for Europe and Central Asia. In: Rounsevell M, Fischer M, Torre-Marin Rando A, Mader A (eds) Secretariat of the Intergovernmental SciencePolicy Platform on Biodiversity and Ecosystem Services, Bonn

Hauck J, Winkler KJ, Priess JA (2015) Reviewing drivers of ecosystem change as input for environmental and ecosystem services modelling. Sustain Water Qual Ecol 5:9-30. https://doi.org/10.1016/j. swaqe.2015.01.003

Hauck J, Schleyer C, Priess JA, Veerkamp CJ, Dunford R, Alkemade R, Berry P, Primmer E, Kok M, Young J (2019) Combining policy analyses, exploratory scenarios, and integrated modelling to assess land use policy options. Environ Sci Pol 94:202-210. https://doi. org/10.1016/j.envsci.2018.12.009

Hawkins BA, Cornell HV (1994) Maximum parasitism rates and successful biological control. Science 266:1886-1887. https://doi.org/10. 1126/science. 266.5192 .1886

Hof C, Voskamp A, Biber MF, Böhning-Gaese K, Engelhardt EK, Niamir A, Willis SG, Hickler R (2018) Bioenergy cropland expansion may offset positive effects of climate change mitigation for global vertebrate diversity. Proc Natl Acad Sci U S A 115:13294 13299. https://doi.org/10.1073/pnas.1807745115

Hootsmans RM, Bouwman AF, Leemans R, Kreileman GJJ (2001) Modelling land degradation in IMAGE 2. RIVM, Bilthoven

Hurtt GC, Chini LP, Frolking S, Betts R, Feddema J, Fischer G, Fisk JP, Hibbard K, Houghton RA, Janetos A (2011) Harmonization of landuse scenarios for the period 1500-2100: 600 years of global gridded annual land-use transitions, wood harvest, and resulting secondary lands. Clim Chang 109:117-161. https://doi.org/10.1007/s10584011-0153-2

IPBES (2016) Summary for policymakers of the methodological assessment report on scenarios and models of biodiversity and ecosystem services of the Intergovernmental Science-Policy Platform on Biodiversity and Ecosystem Services. In: Ferrier S, Ninan KN, Leadley P, Alkemade R, Acosta LA, Akçakaya HR, Brotons L, Cheung WWL, Christensen V, Harhash KA, Kabubo-Mariara J, Lundquist C, Obersteiner M, Pereira HM, Peterson G, PichsMadruga R, Ravindranath N, Rondinini C, Wintle BA (eds) Secretariat of the Intergovernmental Science-Policy Platform on Biodiversity and Ecosystem Services, Bonn

IPBES (2019) Summary for policymakers of the global assessment on biodiversity and ecosystem services of the Intergovernmental Science-Policy Platform on Biodiversity and Ecosystem Services. Díaz S, Settele J, Brondízio ES, Ngo HT, Guèze M Agard J, Arneth A, Balvanera P, Brauman KA, Butchart SHM, Chan KMA, Garibaldi LA, Ichii K, Liu J, Subramanian SM, Midgley GF, Miloslavich P, Molnár Z, Obura D, Pfaff A, Polasky S, Purvis A, Razzaque J, Reyers B, Roy Chowdhury R, Shin YJ, VisserenHamakers IJ, Willis KJ, Zayas CN (eds) IPBES Secretariat, Bonn. https://doi.org/10.5281/zenodo.3553579

IPCC (2000) Special report on emission scenarios. A Special Report of Working Group III of the Intergovernmental Panel on Climate Change, Cambridge University Press, Cambridge 
IPCC (2014) Climate change 2014: synthesis report. Contribution of working groups I, II and III to the fifth assessment report on the Intergovernmental Panel on Climate Change. Core Writing team, Pachauri RK, Meyer LA (eds) IPCC, Geneva

IPCC (2019) Summary for policymakers. In Climate change and land: an IPCC special report on climate change, desertification, land degradation, sustainable land management, food security, and greenhouse gas fluxes in terrestrial ecosystems. Shukla PR, Skea J, Calvo Buendia E, Masson-Delmotte V, Portner HO, Roberts DC, Zhai P, Slade R, Connors S, van Diemen R, Ferrat M, Haughey E, Luz S, Neogi S, Pathak M, Petzold J, Portugal Pereira J, Vyas P, Huntley E, Kissick K, Belkacemi M, Malley J (eds) In press

Kim H, Rosa IM, Alkemade R, Leadley P, Hurtt G, Popp A, Van Vuuren DP, Anthoni P, Arneth A, Baisero D (2018) A protocol for an intercomparison of biodiversity and ecosystem services models using harmonized land-use and climate scenarios. Geosci Model Dev 11. https://doi.org/10.5194/gmd-11-4537-2018

Kirchner M, Schmidt J, Kindermann G, Kulmer V, Mitter H, Prettenthaler F, Rüdisser J, Schauppenlehner T, Schönhart M, Strauss F (2015) Ecosystem services and economic development in Austrian agricultural landscapes - the impact of policy and climate change scenarios on trade-offs and synergies. Ecol Econ 109: 161-174. https://doi.org/10.1016/j.ecolecon.2014.11.005

Kleijn D, Sutherland W (2003) How effective are European agrienvironment schemes in conserving and promoting biodiversity? J Appl Ecol 40:947-969. https://doi.org/10.1111/j.1365-2664.2003. 00868.x

Kok MT, Alkemade R, Bakkenes M, van Eerdt M, Janse J, Mandryk M, Kram T, Lazarova T, Meijer J, van Oorschot M (2018) Pathways for agriculture and forestry to contribute to terrestrial biodiversity conservation: a global scenario-study. Biol Conserv 221:137-150. https://doi.org/10.1016/j.biocon.2018.03.003

Krause A, Pugh TA, Bayer AD, Doelman JC, Humpenöder F, Anthoni P, Olin S, Bodirsky BL, Popp A, Stehfest E (2017) Global consequences of afforestation and bioenergy cultivation on ecosystem service indicators. Biogeosciences 14:4829-4850. https://doi.org/ $10.5194 /$ bg-14-4829-2017

Kraxner F, Nordström E-M, Havlík P, Gusti M, Mosnier A, Frank S, Valin H, Fritz S, Fuss S, Kindermann G (2013) Global bioenergy scenarios - future forest development, land-use implications, and trade-offs. Biomass Bioenergy 57:86-96. https://doi.org/10.1016/j. biombioe.2013.02.003

Lautenbach S, Mupepele A-C, Dormann CF, Lee H, Schmidt S, Scholte SSK, Seppelt R, van Teeffelen AJA, Verhagen W, Volk M (2019) Blind spots in ecosystem services research and challenges for implementation. Reg Environ Chang 19:2151-2172. https://doi.org/ 10.1007/s10113-018-1457-9

MA (2005a) Ecosystems and human well-Being: Synthesis. Millennium Ecosystem Assessment, Island Press, Washington DC

MA (2005b) Ecosystems and human well-being: scenarios. Millennium Ecosystem Assessment, Island Press, Washington DC

Martínez-Harms MJ, Balvanera P (2012) Methods for mapping ecosystem service supply: a review. Int J Biodivers Sci Ecosyst Serv Manag 8:17-25. https://doi.org/10.1080/21513732.2012.663792

Meehl GA, Covey C, Delworth T, Latif M, McAvaney B, Mitchell JFB, Stouffer RJ, Taylor KE (2007) The WCRP CMIP3 multimodel dataset: a new era in climate change research. Bull Am Meteorol Soc 88:1383-1394. https://doi.org/10.1175/BAMS-88-9-1383

Mouchet MA, Rega C, Lasseur R, Georges D, Paracchini M-L, Renaud J, Stürck J, Schulp CJE, Verburg PH, Verkerk PJ (2017) Ecosystem service supply by European landscapes under alternative land-use and environmental policies. Int J Biodivers Sci Ecosyst Serv Manag 13:342-354. https://doi.org/10.1080/21513732.2017.1381167

Navarro LM, Pereira HM (2015) Rewilding abandoned landscapes in Europe. In: Navarro LM, Pereira HM (eds) Rewilding European landscapes. Springer, Cham. https://doi.org/10.1007/978-3-31912039-3

Nunez S, Arets E, Alkemade R, Verwer C, Leemans R (2019) Assessing the impacts of climate change on biodiversity: is below $2^{\circ} \mathrm{C}$ enough? Clim Chang 154:351-365. https://doi.org/10.1007/ s10584-019-02420-x

O’Neill BC, Kriegler E, Ebi KL, Kemp-Benedict E, Riahi K, Rothman DS, van Ruijven BJ, van Vuuren DP, Birkmann J, Kok K (2015) The roads ahead: narratives for shared socioeconomic pathways describing world futures in the 21st century. Glob Environ Chang 24:169-180. https://doi.org/10.1016/j.gloenvcha.2015.01.004

Pichs-Madruga R, Obersteiner M, Cantele M, Ahmed MT, Cui X, Cury P, Fall S, Kellner K, Verburg P (2016) Building scenarios and models of drivers of biodiversity and ecosystem change. Chapter 3 in IPBES (2016): the methodological assessment report on scenarios and models of biodiversity and ecosystem services. In: Ferrier S, Ninan KN, Leadley P, Alkemade R, Acosta LA, Akçakaya HR, Brotons L, Cheung WWL, Christensen V, Harhash KA, KabuboMariara J, Lundquist C, Obersteiner M, Pereira HM, Peterson G, Pichs-Madruga R, Ravindranath N, Rondinini C, Wintle BA (eds) Secretariat of the Intergovernmental Science-Policy Platform for Biodiversity and Ecosystem Services, Bonn

Posthumus H, Rouquette J, Morris J, Gowing D, Hess T (2010) A framework for the assessment of ecosystem goods and services; a case study on lowland floodplains in England. Ecol Econ 69:1510-1523. https://doi.org/10.1016/j.ecolecon.2010.02.011

Prestele R, Alexander P, Rounsevell MD, Arneth A, Calvin K, Doelman J, Eitelberg DA, Engström K, Fujimori S, Hasegawa T (2016) Hotspots of uncertainty in land-use and land-cover change projections: a global-scale model comparison. Glob Environ Chang 22: 3967-3983. https://doi.org/10.1111/gcb.13337

Priess J, Schweitzer C, Batkhishig O, Koschitzki T, Wurbs D (2015) Impacts of agricultural land-use dynamics on erosion risks and options for land and water management in Northern Mongolia. Environ Earth Sci 73:697-708. https://doi.org/10.1007/s12665014-3380-9

Priess JA, Hauck J, Haines-Young R, Alkemade R, Mandryk M, Veerkamp C, Gyorgyi B, Dunford R, Berry P, Harrison P (2018) New EU-scale environmental scenarios until 2050 - scenario process and initial scenario applications. Ecosyst Serv 29:542-551. https://doi.org/10.1016/j.ecoser.2017.08.006

Reidsma P, Tekelenburg T, Van den Berg M, Alkemade R (2006) Impacts of land-use change on biodiversity: an assessment of agricultural biodiversity in the European Union. Agric Ecosyst Environ 114:86-102. https://doi.org/10.1016/j.agee.2005.11.026

Rockström J, Steffen W, Noone K, Persson Å, Chapin FS, Lambin E, Lenton TM, Scheffer M, Folke C, Schellnhuber HJ, Björn N, De Wit CA, Hughes T, Van Der Leeuw S, Rodhe H, Sörlin S, Snyder PK, Costanza R, Svedin U, Falkenmark M, Karlberg L, Corell RW, Fabry VJ, Hansen J, Walker B, Liverman D, Richardson K, Crutzen P, Foley J (2009) Planetary boundaries: exploring the safe operating space for humanity. Ecol Soc 14:32

Rodríguez J, Beard TD Jr, Bennett E, Cumming G, Cork S, Agard J, Dobson A, Peterson G(2006) Trade-offs across space, time, and ecosystem services. Ecol Soc 11:28

Rondinini C, Visconti P (2015) Scenarios of large mammal loss in Europe for the 21st century. Conserv Biol 29:1028-1036. https:// doi.org/10.1111/cobi.12532

Rosa IMD, Pereira HM, Ferrier S, Alkemade R, Acosta LA, Akcakaya HR, den Belder E, Fazel AM, Fujimori S, Harfoot M, Harhash KA, Harrison PA, Hauck J, Hendriks RJJ, Hernández G, Jetz W, Karlsson-Vinkhuyzen SI, Kim HJ, King N, Kok MTJ, Kolomytsev GO, Lazarova T, Leadley P, Lundquist CJ, García Márquez J, Meyer C, Navarro LM, Nesshöver C, Ngo HT, Ninan KN, Palomo MG, Pereira LM, Peterson GD, Pichs R, Popp A, Purvis A, Ravera F, Rondinini C, Sathyapalan J, Schipper AM, 
Seppelt R, Settele J, Sitas N, van Vuuren D (2017) Multiscale scenarios for nature futures. Nat Ecol Evol 1:1416-1419. https://doi. org/10.1038/s41559-017-0273-9

Schils R, Olesen JE, Kersebaum K-C, Rijk B, Oberforster M, Kalyada V, Khitrykau M, Gobin A, Kirchev H, Manolova V (2018) Cereal yield gaps across Europe. Eur J Agron 101:109-120. https://doi.org/10. 1016/j.eja.2018.09.003

Schipper AM, Bakkenes M, Meijer J, Alkemade R, Hujbregts M (2016) The GLOBIO model. A technical description of version 3.5. PBL Netherlands Environmental Assessment Agency, The Hague

Schipper AM, Hilbers JP, Meijer JR, Antão LH, Benítez-López A, de Jonge MJM, Leemans LH, Scheper E, Alkemade R, Doelman JC (2020) Projecting terrestrial biodiversity intactness with GLOBIO 4. Glob Chang Biol 26:760-771. https://doi.org/10.1111/gcb.14848

Schmitz C, van Meijl H, Kyle P, Nelson GC, Fujimori S, Gurgel A, Havlik P, Heyhoe E, d'Croz DM, Popp A (2014) Land-use change trajectories up to 2050: insights from a global agro-economic model comparison. J Agric Econ 45:69-84. https://doi.org/10.1111/agec. 12090

Schröter D, Cramer W, Leemans R, Prentice IC, Araújo MB, Arnell NW, Bondeau A, Bugmann H, Carter TR, Gracia CA (2005) Ecosystem service supply and vulnerability to global change in Europe. Science 310:1333-1337. https://doi.org/10.1126/science.1115233

Schröter M, Koellner T, Alkemade R, Arnhold S, Bagstad KJ, Erb K-H, Frank K, Kastner T, Kissinger M, Liu J (2018) Interregional flows of ecosystem services: concepts, typology and four cases. Ecosyst Serv 31:231-241. https://doi.org/10.1016/j.ecoser.2018.02.003

Schulp CJ, Nabuurs G-J, Verburg PH (2008) Future carbon sequestration in Europe - effects of land use change. Agric Ecosyst Environ 127: 251-264. https://doi.org/10.1016/j.agee.2008.04.010

Schulp CJE, Alkemade R, Klein Goldewijk K, Petz K (2012) Mapping ecosystem functions and services in Eastern Europe using globalscale data sets. Int J Biodivers Sci Ecosyst Serv Manag 8:156-168. https://doi.org/10.1080/21513732.2011.645880

Schulp C, Van Teeffelen A, Tucker G, Verburg P (2016) A quantitative assessment of policy options for no net loss of biodiversity and ecosystem services in the European Union. Land Use Policy 57: 151-163. https://doi.org/10.1016/j.landusepol.2016.05.018

Steen-Olsen K, Weinzettel J, Cranston G, Ercin AE, Hertwich EG (2012) Carbon, land, and water footprint accounts for the European Union: consumption, production, and displacements through international trade. Environ Sci Technol 46:10883-10891. https://doi.org/10. 1021/es301949t

Steffen W, Richardson K, Rockström J, Cornell SE, Fetzer I, Bennett EM, Biggs R, Carpenter SR, De Vries W, De Wit CA (2015) Planetary boundaries: guiding human development on a changing planet. Science 347:1259855. https://doi.org/10.1126/science. 1259855

Stehfest E, Bouwman L, Van Vuuren DP, Den Elzen MG, Eickhout B, Kabat P (2009) Climate benefits of changing diet. Clim Chang 95: 83-102. https://doi.org/10.1007/s10584-008-9534-6

Stehfest E, van Vuuren D, Kram T, Bouwman L, Alkemade R, Bakkenes M, Biemans H, Bouwman A, den Elzen M, Janse J, Lucas P, van Minnen J, Muller M, Prins A (2014) Integrated assessment of global environmental change with IMAGE 3.0 model description and policy applications. PBL Netherlands Environmental Assessment Agency, The Hague

Stehfest E, van Zeist W-J, Valin H, Havlik P, Popp A, Kyle P, Tabeau A, Mason-D’Croz D, Hasegawa T, Bodirsky BL (2019) Key determinants of global land-use projections. Nat Commun 10:2166. https:// doi.org/10.1038/s41467-019-09945-w

Thuiller W, Guéguen M, Renaud J, Karger DN, Zimmermann NE (2019) Uncertainty in ensembles of global biodiversity scenarios. Nat Commun 10:1-9. https://doi.org/10.1038/s41467-019-09519-w

Tittensor DP, Walpole M, Hill SL, Boyce DG, Britten GL, Burgess ND, Butchart SHM, Leadley PW, Regan EC, Alkemade R (2014) A midterm analysis of progress toward international biodiversity targets. Science 346:241-244. https://doi.org/10.1126/science.1257484

Török P, Vida E, Deák B, Lengyel S, Tóthmérész B (2011) Grassland restoration on former croplands in Europe: an assessment of applicability of techniques and costs. Biodivers Conserv 20:2311-2332. https://doi.org/10.1007/s10531-011-9992-4

UN (2015) Transforming our world: the 2030 agenda for sustainable development. United Nations, New York

Van Buskirk J, Willi Y (2004) Enhancement of farmland biodiversity within set-aside land. Conserv Biol 18:987-994. https://doi.org/10. 1111/j.1523-1739.2004.00359.x

Van Vuuren DP, Carter TR (2014) Climate and socio-economic scenarios for climate change research and assessment: reconciling the new with the old. Clim Chang 122:415-429. https://doi.org/10.1007/ s10584-013-0974-2

Verboom J, Alkemade R, Klijn J, Metzger MJ, Reijnen R (2007) Combining biodiversity modeling with political and economic development scenarios for $25 \mathrm{EU}$ countries. Ecol Econ 62:267-276. https://doi.org/10.1016/j.ecolecon.2006.04.009

Visconti P, Bakkenes M, Baisero D, Brooks T, Butchart SH, Joppa L, Alkemade R, Di Marco M, Santini L, Hoffmann M (2016) Projecting global biodiversity indicators under future development scenarios. Conserv Lett 9:5-13. https://doi.org/10.1111/conl.12159

Volk M (2013) Modelling ecosystem services - challenges and promising future directions. Sustain Water Qual Ecol 1:3-9. https://doi.org/ 10.1016/j.swaqe.2014.05.003

Willett W, Rockström J, Loken B, Springmann M, Lang T, Vermeulen S, Garnett T, Tilman D, DeClerck F, Wood A (2019) Food in the Anthropocene: the EAT-Lancet Commission on healthy diets from sustainable food systems. Lancet 393:447-492. https://doi.org/10. 1016/S0140-6736(18)31788-4

Wilting HC, Schipper AM, Bakkenes M, Meijer JR, Huijbregts MA (2017) Quantifying biodiversity losses due to human consumption: a global-scale footprint analysis. Environ Sci Technol 51:32983306. https://doi.org/10.1021/acs.est.6b05296

Zaehle S, Bondeau A, Carter TR, Cramer W, Erhard M, Prentice IC, Reginster I, Rounsevell MDA, Sitch S, Smith B (2007) Projected changes in terrestrial carbon storage in Europe under climate and land-use change, 1990-2100. Ecosystems 10:380-401. https://doi. org/10.1007/s10021-007-9028-9

Publisher's note Springer Nature remains neutral with regard to jurisdictional claims in published maps and institutional affiliations. 